\title{
EDITORIAL
}

\section{Critical illness-related corticosteroid insufficiency and community-acquired pneumonia: back to the future!}

\author{
D. Annane*, G. Umberto Meduri ${ }^{\#}$ and P. Marik ${ }^{\#}$
}

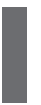
$\mathrm{n}$ the past decade, emphasis in the study of the pathogenesis of infectious diseases has shifted from determining the function of the cellular players in the inflammatory response to the mediators that orchestrate activation and regulation of this response [1]. According to current thinking, pulmonary sepsis begins when pathogens invade the sterile lower respiratory tract, leading to activation of the innate immune response to produce local and systemic inflammation [2]. Whereas restricted inflammation is beneficial, excessive or persistent inflammation incites tissue destruction and disease [3]; it is the lack of regulation (dysregulated systemic inflammation) of this vital response that is central to the pathogenesis of sepsis-associated morbidity and mortality [2, 4]. Among patients with community-acquired pneumonia (CAP), nonsurvivors, unlike survivors, exhibit persistent elevation in plasma inflammatory cytokine levels over time [5-7].

An intact hypothalamic-pituitary-adrenal (HPA) axis with effective intracellular glucocorticoid anti-inflammatory activity is indispensable for host survival after exposure to an infectious agent [8]. That the integrity of the axis is fundamental to surviving critical illness has been well demonstrated by the increased risk of death following: removal of the adrenal cortex in lipopolysaccharide-challenged animals [9]; bilateral adrenal haemorrhage in patients with severe sepsis [10]; and inadvertent suppression of cortisol synthesis in trauma patients who received etomidate for sedation [11]. Advancements in molecular biology have provided greater understanding about activation of the HPA axis during sepsis [12]. Briefly, autonomic nervous afferent fibres sense the threat at the tissue level and signal through brain stem nuclei in the hypothalamus. Simultaneously, circulating cytokines enter the brain in areas lacking a bloodbrain barrier and migrate to the hypothalamus where they directly stimulate the synthesis of corticotrophin-releasing hormone. Similarly, inflammatory cytokines can also directly stimulate adrenocorticotropic hormone (ACTH) and cortisol synthesis. The increase in ACTH and cortisol levels usually

*General Intensive Care Unit, Raymond Poincaré Hospital, University of Versailles SQY (UniverSud Paris), Garches, France. "Division of Pulmonary, Critical Care, and Sleep Medicine, University of Tennessee Health Science Centre and Memphis Veterans Affairs Medical Center, Memphis, TN, USA.

STATEMENT OF INTEREST: None declared

CORRESPONDENCE: D. Annane, General Intensive Care Unit, Raymond Poincaré Hospital, University of Versailles SQY (UniverSud Paris), 104 boulevard Raymond Poincaré, 92380 Garches, France. Fax: 33 147107783. E-mail: Djillali.annane@rpc.aphp.fr parallels circulating levels of interleukin (IL)-6, an important pro-inflammatory mediator.

The prognostic value of circulating levels of cortisol has been reported in various critical illnesses (P. Marik, personal communication). In this issue of the European Respiratory Journal, Gотон et al. [13] report a good correlation between cortisol levels and the Pneumonia Patient Outcomes Research Team (PORT) score (a severity index score), in-hospital death and length of hospital stay in a cohort of 64 patients with CAP. Their findings are in line with those of a recent larger cohort of patients, which identified basal total cortisol as the best independent predictor of outcome in patients with mild-tosevere CAP [14]. In addition, GOTOH et al. [13] provide evidence that ACTH levels and delta cortisol correlated with severity of illness. However, the ACTH and cortisol levels were rather low (median of $20 \mathrm{pg} \cdot \mathrm{mL}^{-1}$ and $21.3 \mu \mathrm{g} \cdot \mathrm{dL}^{-1}$, respectively), suggesting that almost half of these patients had inappropriate HPA axis activation for the severity of their illness. According to the lower limit of the ranges for cortisol $\left(9.3 \mu \mathrm{g} \cdot \mathrm{L}^{-1}\right)$ and delta cortisol $\left(2.2 \mu \mathrm{g} \cdot \mathrm{dL}^{-1}\right)$, at least nine patients met the criteria for critical illness-related corticosteroid insufficiency (CIRCI).

CIRCI was recently proposed by an expert panel to describe the dysfunction of the HPA axis that occurs during the continuum of sepsis-associated systemic inflammation and other critical illnesses (P. Marik, personal communication). CIRCI is defined as inadequate intracellular glucocorticoid anti-inflammatory activity for the severity of the patient's

\begin{tabular}{|c|c|c|c|c|}
\hline First author [ref.] & $\begin{array}{c}\text { Treatment } \\
\mathbf{n} / \mathbf{N}^{\#}\end{array}$ & $\begin{array}{c}\text { Control } \\
n / N^{\star}\end{array}$ & $\begin{array}{c}\text { Weight } \\
\%\end{array}$ & RR $(95 \% \mathrm{Cl})$ \\
\hline WAGNER [15] & $1 / 52$ & $1 / 61$ & 2.08 & $1.17(0.08-18.30)$ \\
\hline ANNANE [16] & $21 / 47$ & $35 / 54$ & 73.51 & $0.69(0.47-1.00)$ \\
\hline Confalonieri [17] & $0 / 23$ & $6 / 23$ & 14.67 & $0.08(0.00-1.29)$ \\
\hline NAWAB [18] & $3 / 18$ & $3 / 7$ & 9.75 & $0.39(0.10-1.49)$ \\
\hline Total & 140 & 145 & 100.00 & $0.58(0.40-0.83)$ \\
\hline
\end{tabular}

$\mathrm{RR}$ : relative risk; $\mathrm{Cl}$ : confidence interval. The heterogeneity test found the following: Chi-squared 3.38, degree of freedom $3(p=0.34), 1^{2} 11.3 \%$. The test of the overall effect found the following: Z-value 2.95, $p=0.003 .{ }^{*}: 25$ total events; $\uparrow: 45$ total events 


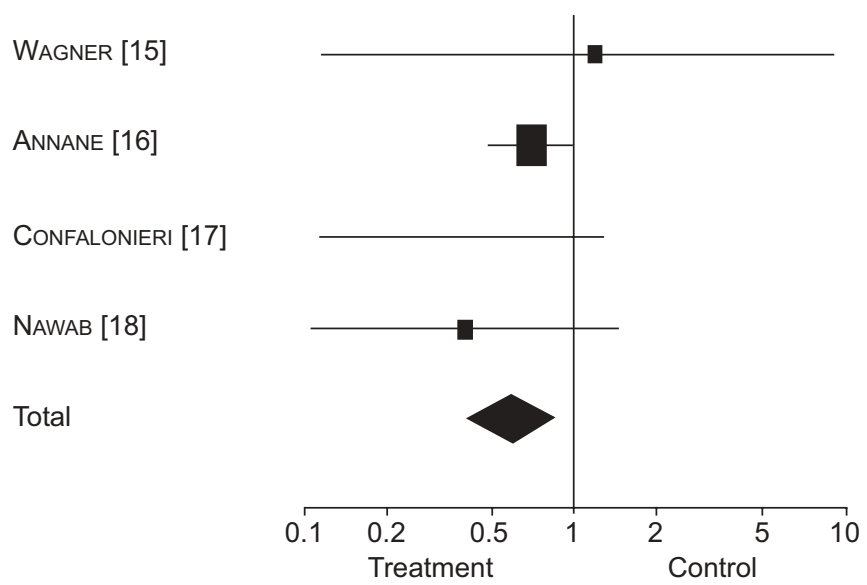

FIGURE 1. Peto diagram showing effects of corticosteroids in communityacquired pneumonia. Relative risk (RR) of short-term mortality and $95 \%$ confidence intervals are given for individual studies as well as the pooled estimate of relative risk. Analysis was performed using fixed effects. The use of corticosteroids was associated with a $42 \%$ reduction in the RR of death and the test for heterogeneity suggested consistency in studies' results.

illness. In the simplest terms, CIRCI can result from either insufficient availability of glucocorticoid to the cell or from intracellular resistance/insensitivity to corticoids (despite elevated circulating cortisol). GотоH et al. [13] did not investigate tissue resistance to glucocorticoid nor did they measure circulating levels of cytokines to better define the relationship between the intensity of the systemic inflammation and endogenous cortisol release. It is paramount that future research studies report the cortisol and ACTH levels, together with markers reflecting the degree of activation of the pro-inflammatory response (e.g. IL-6, nuclear factor- $\kappa \mathrm{B}$, etc.).

Recognition of the fact that CIRCI may complicate CAP raises the issue of glucocorticoid replacement therapy. In the cohort studied by Gотон et al. [13], 14 patients were treated with glucocorticoids. As early as 1955, favourable effects of hydrocortisone $\left(80 \mathrm{mg} \cdot\right.$ day $^{-1}$ orally) were reported in patients with pneumococcal pneumonia [15]. More recently, benefit from a 7-day treatment with hydrocortisone $\left(200 \mathrm{mg} \cdot\right.$ day $\left.^{-1}\right)$ plus fludrocortisone $\left(50 \mu \mathrm{g} \cdot \mathrm{day}^{-1}\right)$ was reported in 300 septic shock patients; 101 of these patients (54 in the placebo group and 47 in the steroid group) had CAP [16]. There were a total of $35(65 \%)$ and $21(45 \%)$ deaths at day 28 (hazard ratio 0.55; $95 \%$ confidence interval (CI) $0.32-0.95$ ) in the placebo and steroid groups, respectively (data not presented in [16]; D. Annane, personal communication). Another randomised, placebo-controlled trial showed that a 7-day treatment with $240 \mathrm{mg} \cdot \mathrm{day}^{-1}$ of hydrocortisone was associated with a significant reduction in length of hospital stay (13 versus 21 days; $p=0.03$ ) and mortality (0 versus 30\%; $p=0.009$ ) [17]. Finally, NAWAB et al. [18] performed a randomised trial that investigated prolonged methylprednisolone infusion $\left(1 \mathrm{mg} \cdot \mathrm{kg}^{-1} \cdot\right.$ day $\left.^{-1}\right)$ in 91 patients with early acute respiratory distress syndrome, with many of the cases caused by severe CAP. Among eligible patients with severe CAP, methylprednisolone-treated patients had a higher rate of extubation (61 versus 14\%; $\mathrm{p}=0.07$ ) and a mean \pm SD lower
C-reactive protein $(2.5 \pm 1.8$ versus $12.1 \pm 8.1 ; \mathrm{p}=0.06)$ by day 7 . Treatment was associated with a reduction in median duration of mechanical ventilation (5 versus 10 days; $\mathrm{p}=0.13$ ) and hospital mortality (16.5 versus $42.5 \% ; \mathrm{p}=0.3$ ). Pooling the results from these trials suggests that prolonged treatment with moderate-dose corticosteroids reduces short-term mortality in patients with CAP (relative risk 0.58 ; 95\% CI $0.40-0.83$; table 1 and fig. 1).

Given the small size of these trials and some heterogeneity across the studies $\left(\mathrm{I}^{2}=11.2 \%\right)$, additional adequately powered studies are required before the routine use of prolonged glucocorticoid treatment in patients with community-acquired pneumonia can be recommended.

\section{REFERENCES}

1 Wilson M, Seymour R, Henderson B. Bacterial perturbation of cytokine networks. Infect Immun 1998; 66: 2401-2409.

2 Englert JA, Fink MP. The multiple organ dysfunction syndrome and late-phase mortality in sepsis. Curr Infect Dis Rep 2005; 7: 335-341.

3 Suffredini AF, Fantuzzi G, Badolato R, Oppenheim JJ, O'Grady NP. New insights into the biology of the acute phase response. J Clin Immunol 1999; 19: 203-214.

4 Mizgerd JP. Acute lower respiratory tract infection. N Engl J Med 2008; 358: 716-727.

5 Fernandez-Serrano S, Dorca J, Coromines M, Carratala J, Gudiol F, Manresa F. Molecular inflammatory responses measured in blood of patients with severe communityacquired pneumonia. Clin Diagn Lab Immunol 2003; 10: 813-820.

6 Kellum JA, Kong L, Fink MP, et al. Understanding the inflammatory cytokine response in pneumonia and sepsis: results of the Genetic and Inflammatory Markers of Sepsis (GenIMS) study. Arch Intern Med 2007; 167: 1655-1663.

7 Lekkou A, Karakantza M, Mouzaki A, Kalfarentzos F, Gogos CA. Cytokine production and monocyte HLA-DR expression as predictors of outcome for patients with community-acquired severe infections. Clin Diagn Lab Immunol 2004; 11: 161-167.

8 Annane D, Sebille V, Troche G, Raphael JC, Gajdos P, Bellissant E. A 3-level prognostic classification in septic shock based on cortisol levels and cortisol response to corticotropin. JAMA 2000; 283: 1038-1045.

9 Witek-Janusek L, Yelich MR. Role of the adrenal cortex and medulla in the young rats' glucoregulatory response to endotoxin. Shock 1995; 3: 434-439.

10 Waterhouse R. Case of suprarenal apoplexy. Lancet 1911; 1 : 577.

11 Ledingham IM, Watt I. Influence of sedation on mortality in critically ill multiple trauma patients. Lancet 1983; 1: 1270.

12 Maxime V, Shidasp S, Annane D. Metabolism modulators in sepsis: the abnormal pituitary response. Crit Care Med 2007; 35: Suppl. 9, S596-S601.

13 Gotoh S, Nishimura N, Takahashi O, et al. Adrenal function in patients with community-acquired pneumonia Eur Respir J 2008; 31: 1268-1273.

14 Christ-Crain M, Stolz D, Jutla S, et al. Free and total cortisol levels as predictors of severity and outcome in 
community-acquired pneumonia. Am J Respir Crit Care Med 2007; 176: 913-920.

15 Wagner HN, Bennett IL, Lasagna L, Cluff LE, Rosenthal MB, Mirick GS. The effect of hydrocortisone upon the course of pneumococcal pneumonia treated with penicillin. Bulletin of Johns Hopkins Hospital 1955; 98 : 197-215.

16 Annane D, Sebille V, Charpentier C, et al. Effect of treatment with low doses of hydrocortisone and fludrocortisone on mortality in patients with septic shock. JAMA 2002; 288: 862-871.

17 Confalonieri M, Urbino R, Potena A, et al. Hydrocortisone infusion for severe community-acquired pneumonia: a preliminary randomized study. Am J Respir Crit Care Med 2005; 171: 242-248.

18 Nawab Q, Golden E, Confalonieri M, Umberger R, Meduri G. Glucocorticoid treatment in severe community-acquired pneumonia. Am J Respir Crit Care Med 2007; 175: A594. 